\title{
AINDA QUE TENHAMOS CHEGADO AOS 50 COM MUITAS REALIZAÇÕES, TEMOS QUE OLHAR PARA O FUTURO SABENDO QUE AINDA HÁ MUITO QUE FAZER...
}

Ao completar 50 anos, o INPA vivencia um momento singular da sua história que, se por um lado é cercado de simbolismos e emoções, por outro também invoca um momento de reflexão sobre onde estamos e para onde vamos. Simbolismo e emoção brotam da constatação que nada chega a meio século de existência, "impunemente". Para várias dezenas ou mesmo centenas de pessoas, o INPA foi, tem sido e continuará sendo, a "segunda casa". Histórias, lendas e crendices, que poderiam se transformar em um volume especial da Acta Amazonica, fazem parte deste nosso mundo do INPA, cheio de figuras folclóricas e aventuras memoráveis, associadas ao desbravamento científico da Amazônia. E como fruto do empreendedorismo de cientistas, técnicos e administradores, neste meio século de existência o INPA se consolidou como uma referência sobre o conhecimento científico da região Amazônica, especialmente no meio acadêmico. Porém, ainda freqüentemente somos questionados sobre o quanto deste conhecimento tem sido disponibilizado para quem realmente precisa, ou seja, para as populações locais. Negar que o conhecimento produzido é de altíssima utilidade é um grande erro. Ao mesmo tempo também acredito que haja espaço para questionarmos se não poderíamos ter feito mais. Logicamente fizemos muito, e o conhecimento e as tecnologias do INPA podem ser vistos nas mais diversas áreas, desde a piscicultura, até a tecnologia de alimentos, saúde, tecnologias da madeira, agronomia e nas questões da biodiversidade em geral, somente para nomear algumas áreas importantes. Mas podemos fazer mais e, neste sentido, em 2004 vivemos no INPA a expectativa de estarmos na ante-sala de novos tempos. Estamos trabalhando para dotar o instituto de mecanismos e procedimentos que lhe permitam enfrentar sem sobressaltos a nova realidade e conjuntura que vivemos. A velocidade com que novas tecnologias tornam-se disponíveis, a importância estratégica da Amazônia para o Brasil e para o mundo, a crescente demanda da sociedade local sobre as questões ambientais, o novo quadro político, social e econômico do país, entre outros fatores, forçam o INPA a continuamente se modernizar e se reestruturar, para poder continuar cumprir eficientemente a sua missão de gerar conhecimento para o desenvolvimento sustentável da Amazônia. Ainda que tenhamos chegado na meia idade com muitas realizações, temos que olhar para o futuro sabendo que há ainda muito que fazer. Oxalá possa o INPA completar seu centenário plenamente reconhecido pela sociedade em geral como uma instituição estratégica e necessária à região Amazônia. Isto é perfeitamente possível e depende do esforço de todos funcionários.

Por outro lado, se a tarefa de fazer ciência e gerar conhecimento na Amazônia é complexa e permeada de desafios, a missão de divulgar esta ciência e os conhecimentos adquiridos deve ser encarada como um trabalho de altíssima prioridade e de enorme responsabilidade. A história da Acta Amazonica é parte ativa e marcante da própria história do INPA. Em 2004, enquanto o INPA completa 50 anos, a AA publica seu $34^{\circ}$ volume. São mais de três décadas de existência e várias centenas trabalhos publicados, sobre os mais variados assuntos relacionados com o ambiente físico e a biodiversidade, as questóes sociais e as interações ecológicas, na Amazônia. Logicamente estes trinta e quatro anos de existência só foram possíveis porque um grande número de profissionais tiveram, em um momento ou outro, o altruísmo de dedicar parte do seu tempo para viabilizar a publicação desta revista que é, hoje, reconhecidamente, uma referência importante sobre a Amazônia. Na impossibilidade de nomear todo(a)s envolvido(a)s, tomo a liberdade de usar 


\section{ACTA AMAZONICA}

o nome da Profa. Algenir Ferraz Suano da Silva para, em seu nome, homenagear todos que direta ou indiretamente estiveram envolvidos na publicação da AA desde o seu inicio até hoje.

Ainda que ao longo destas três décadas tenhamos passado por fases difíceis, invariavelmente capitaneadas pelos escassos recursos que provocaram atrasos e irregularidades na publicação de alguns fascículos, chegamos em 2004 com ótimas perspectivas de consolidar a nossa revista, definitivamente, como uma referência de nível internacional sobre a ciência Amazônica. Há pouco mais de dois anos iniciamos um processo de reformulação que começa a gerar frutos tangíveis. Com um corpo editorial de alto nível e extremamente dedicado, liderado pelo Dr. George Rebêlo - a quem também deve-se uma especial referência -, o trabalho de reestruturação da AA vem abrangendo não só a estética, mas também as questões administrativas e a própria adequação da revista aos novos tipos de demandas, associadas às novas tecnologias de comunicação. Implementamos a AA em formato digital e a disponibilizamos na página do INPA, na internet; temos hoje um novo formato: maior, esteticamente mais refinado e visualmente mais atrativo; o processamento de artigos passa a ser controlado com softwares especiais, o que agiliza todo o processo editorial; a revista passou a ser parte do SciELO (Scientific Eletronic Library) e seus artigos estão indexados em mais de dez bases de dados importantes, incluindo o Biological Abstracts, Zoological Records e Cambridge Scientific Abstracts Service. Como próximo passo nesta direção, aguardamos ansiosamente a data de entrarmos para o Scientific Citation Index (SCI), o quê não deve demorar muito. Como resultados destes vários avanços, o tempo de processamento dos artigos tem diminuído significativamente e um número maior de artigos submetidos, o que gera a necessidade de um processo seletivo mais rigoroso e, a partir daí, uma conseqüente melhora na qualidade dos trabalhos publicados. Isto, num processo de retro-alimentação positiva, deve tornar a AA ainda mais procurada por autores nacionais e internacionais.

Estar à frente do INPA neste momento e ter a oportunidade de escrever este editorial é motivo de altíssima honra e orgulho pessoal, mas tenho certeza que toda a equipe administrativa compartilha comigo a satisfação de vivenciar este momento. Na verdade, este é um orgulho que transcende esta ou aquela administração, e deve estar sendo vivenciado por cada funcionário do INPA. Este número comemorativo dos 50 anos do nosso instituto, bem merece e precisa ser visto não só como o coroamento do trabalho e do esforço dos inúmeros profissionais que contribuíram para que a AA pudesse se tornar o que ela é hoje, mas como um desafio para que a revista científica do INPA continue a se aperfeiçoar e existir por muitas outras décadas, com muito sucesso. 